Bogdan Kolar

\title{
Novi izzivi za redovništvo v 19. stoletju in posebej za manjše brate
}

\section{New Challenges for Religious Orders and Particularly for the Franciscans at the Beginning of the $19^{\text {th }}$ Century}

Poværetek: Cerkveno življenje nasploh in v njegovem okviru redovne ustanove so bili na začetku 19. stoletja še vedno v znamenju družbenih in cerkvenopolitičnih razmer, ki so bile sad idej državnega cerkvenstva, notranjecerkvenih tokov s konca 18. stoletja in kratkega obdobja francoske oblasti. Manjši bratje so iz tega obdobja izšli kot najmočnejša redovna skupnost na Slovenskem, ker jim je uspelo ohraniti velik del ustanov in izvirno mesto v cerkvenem življenju. Ob nadaljevanju že ustaljenih oblik pastoralnega delovanja so se izrecno zavzemali za odpravo posledic rigorizma v praktičnem verskem življenju in na teološkem področju. Nekateri avtorji so s svojimi spisi pomembno zaznamovali teološko misel 19. stoletja. Imeli so vedno vidnejšo vlogo v župnijskem pastoralnem delu in na področju šolstva in dajali ton praktičnemu verskemu življenju. Pastoralne pobude so manjši bratje morali usklajevati z župnijsko duhovščino in od sredine stoletja dalje še z drugimi redovnimi skupnostmi, ki so vstopale v slovenski prostor. Čeprav so imeli ustaljeno mesto in večje število ustanov iz prejšnjega obdobja, so se morali prilagajati in iskati svoje lastne odgovore na nove izzive, ki jim jih je prinašal čas in s tem spremembe v Cerkvi in v slovenski družbi. Pri tem so pokazali veliko mero sposobnosti za prilagajanje.

Ključne besede: manjši bratje frančiškani, 19. stoletje, teološki tokovi, šolstvo, ljudski misijoni, verski tisk

Abstract: The situation of the Church and within her in the religious orders at the beginning of the $19^{\text {th }}$ century was still influenced by the social and political factors which had been fruit of the Church-state and inside Church ideas from the end of the $18^{\text {th }}$ century and of the short French dominion. The Friars Minor came out of that period as the strongest religious community in Slovenia because they were successful in preserving the major number of convents and their original place in the Church. Along with the carrying on of their traditional pastoral activities they were successful in fighting the consequences of rigorism both in the practical religious life and in the field of theology. Some authors significantly marked the theology of the $19^{\text {th }}$ century with their papers. Hence 
they had a growing importance in the parish pastoral work and in the field of the education giving at the same time a stamp to the practical religious life. They had to coordinate their activities with the secular clergy and since the midcentury with other religious orders that settled in the Slovenian society. In spite of their well established place and a significant number of houses from the previous period they had to adapt and to look for their own answers to the new challenges brought around by the time and the changes both in the Church and in the Slovenian society. They demonstrated a high level of adaptability.

Keywords: friars minor Franciscans, $19^{\text {th }}$ century, theological tendencies, education, popular missions, Church press

Med cerkvenimi ustanovami, ki so najbolj čutile učinke duhovnih in idejnih gibanj $v$ drugi polovici 18. stoletja, sadove francoske revolucije in njenih posledic in so bile po koncu napoleonskega obdobja najbolj ranjene, so bile prav redovne skupnosti. Zaradi tesne vpetosti v širšo družbo in povezanosti z njo, saj so bile del Cerkve in $\mathrm{s}$ tem kot trdna sestavina vključene $v$ ancien régime, so bile deležne represivnih ukrepov $v$ vseh evropskih državah, kjer so prevladale razsvetljenske ideje. Zadnji udarec jim je dodala sekularizacija $v$ začetku 19. stoletja, ki je pometla še v preostalih državah (v nemškem prostoru od 1803 do 1807). Tako kakor vodstvo Cerkve in še zlasti Cerkvena država so redovi v očeh mnogih sodobnikov veljali za od časa oddaljene ustanove, nesposobne, da vzpostavijo stik z novimi intelektualnimi smermi in da odpravijo prevlado aristokratskih cerkvenih struktur iz prejšnjih stoletij, ki niso imele nič skupnega z evangelijem; med njimi je izstopala še vedno veljavna navezanost na fevdalni sistem in na sistem beneficijev (Jedin 1993, 5; 240). V to vrsto navezanosti na staro ureditev je mogoče uvrstiti tudi patronatsko pravo in večino organizacijskih struktur.

\section{Vplivi okoliščin iz širšega prostora}

Za mnoge redovne skupnosti je kljub posameznim izrednim zgledom evangeljskega pričevanja in tudi urejenim odnosom - to je svarilo pred poenostavljenimi posploševanji - veljalo, da niso bile zgovorne pričevalke evangeljskih kreposti. Za ljudi tistega časa so bili samostani predvsem kraji, kjer se zapravlja čas, in kraji neplodnih teoloških razprav in ugodnega življenja, kjer je bila temeljna skrb upravljanje velikih posestev, oskrbovanje razkošnih stanovanj in zapravljanje. Mnoge redovne ustanove, ustanovljene v srednjem veku, so bile napol prazne; to je še bolj kazalo na njihovo negativno pričevanje. Mendikantske skupnosti, ki resda niso izstopale zaradi svojega premoženja, so trpele zaradi pomanjkanja verske zavzetosti in discipline, in čeprav so se med njimi našli posamezniki, ki so bili goreči apostoli ali karitativni delavci, je velik del med njimi pomenil »cerkveni plebs", ki je bil slab zgled za vernike in tarča obrekovalcev redovnih zaobljub. Očitali so jim družbeno nekoristnost, koristnost pa priznavali samo tistim, ki so se izključno posvečali izobraževalnemu delu ali skrbi za bolne. 
Zato ne preseneča ravnanje mnogih vlad, ki so s podporo javnega mnenja podržavljale samostane in njihovo premoženje. Sredstva so uporabljale za ustanavljanje novih župnij, ki so bile potrebne zaradi večanja števila prebivalstva, za podpiranje šolskih dejavnosti in za pomoč potrebnim. Radikalni ukrepi, ki so jih sprejeli francoski revolucionarji, so bili samo krona politike, kakor se je oblikovala v vseh katoliških deželah od začetka 18. stoletja dalje. Med letoma 1748 in 1797 so samo v Beneški republiki na ta način ukinili 127 samostanov. Podobne ukrepe so sprejemale druge države na Apeninskem polotoku, v Španiji in - zelo sistematično - v desetletju od 1780 do 1790 v avstrijski državi (Jedin 1993, 6-7; Wolf 1871). Pobude za radikalne posege na področju redovnih ustanov so prihajale tudi iz cerkvenih vrst. Leta 1768 je nadškof iz Toulousa, Loménie de Brienne, gonilna sila Komisije za redovnike (Commission des réguliers), sposoben gospodar, skrben za dobro ime Cerkve v družbi, a »bliže filozofom kakor krščanstvu«, predlagal kralju vrsto ukrepov na področju redov: povišanje starosti za izpoved zaobljub (to bi bolj zagotavljalo svobodo posameznika), reformo redovnih pravil starih redov (to bi zagotovilo spoštovanje razvoja miselnosti pri njihovem oblikovanju), povečanje nadzorstva krajevnih škofov nad eksemptnimi redovi in določitev najmanjšega števila članov skupnosti, da neka skupnost lahko obstaja. Kmalu je sledilo zatrtje 426 samostanov. Namen omenjene komisije je bila reforma redovnih ustanov in ne njihovo zatiranje, način, kako so to izvedli, pa je bil precedens za ukrepe četrt stoletja pozneje. Mogoče je reči, da so bile redovne skupnosti med vsemi cerkvenimi ustanovami v revolucionarnem dogajanju in tudi v naslednjih desetletjih osrednji cilj protiukrepov. To so bili namreč ukrepi, ki so spominjali na čase barbarskih vpadov in na njihovo uničevanje samostanskih poslopij in ljudi (Jedin 1993, 7; Frank 2010, 154-155). Na Slovenskem je bil med pomembnimi pobudniki za takšne ukrepe ljubljanski škof Janez Karel Herberstein (1719, škof od 1769, 1787) (Dolinar 1991, 157-160).

Če je res, da so v teku 19. stoletja redovne skupnosti postopoma obnavljale svojo podobo in mesto, tudi v smislu gospodarskega delovanja, podpiranja gradbenih del in umetnosti, novih delovnih možnosti in aktivnosti na socialnem področju, so vendarle še vedno obstajale cerkvene skupnosti, v katerih je imela duhovnost (izvirna podoba, ki jo je v Cerkev vnesel ustanovitelj ali ustanoviteljica) prednostno mesto in je ta narekovala način življenja. Zato je pri obravnavanju zgodovine teh skupnosti treba upoštevati tako zunanji vidik in razvoj (različne oblike dejavnosti, vloga na gospodarskem področju) kakor notranjega, ki se je izražal v vsakodnevnem redovnem življenju (razne oblike molitvenega življenja ob delavnikih in praznikih, duhovne vaje in druga duhovno bolj intenzivna obdobja življenja, prekinitev izobraževanja in rednih dejavnosti med noviciatom in v drugih obdobjih redovnega oblikovanja). Temu je bilo namenjenega veliko časa, sredstev in tudi osebja, vendar se je prav na tem področju kazala izvirnost kakega reda ali kongregacije. Marsikdaj so bile prav napetosti v teh segmentih gonilna sila za sprejemanje odločitev in iskanje mesta v Cerkvi (Schmiedl 2004, 71-76).

Samo v redkih deželah je vihar redovnim skupnostim prizanesel, vendar vrnitve na stanje pred velikimi dogodki ni bilo. Razen nekaj desetin redov, ki se niso ob- 
novili, pa je bila od srede 19. stoletja dalje Cerkev priča pravemu razcvetu redovnega življenja. Samo v času ene generacije se je zgodil preporod, ki ga Cerkev v svoji zgodovini ni poznala, ne po obsegu in ne po raznolikosti (Jedin 1993, 240). Obnovljena je bila večina starih redov, ustanovljena pa množica novih, ki so predvsem v Franciji odgovorile na nove zahteve časov in potrebe Cerkve. Kot neke vrste znamenje tega lahko gledamo uradno obnovo Družbe Jezusove v letu 1814 (to je storil papež Pij VII.) in njen razcvet v naslednjih desetletjih; v Avstriji so bili jezuiti po večletnih dogovarjanjih ponovno dovoljeni leta 1827. Od tedaj dalje segajo njihove dejavnosti v tri smeri: vodenje vzgojno-izobraževalnih ustanov, pridigarstvo in ljudski misijoni.

Nove razmere so nastopile po revolucionarnem letu 1848, ko so voditelji Cerkve v Avstriji želeli tudi na tem področju vzpostaviti nove odnose - začela so se večletna pogajanja, ki so nazadnje prinesla leta 1855 konkordat. Čeprav v njem redovniki niso imeli pomembnega mesta, so vendarle določila konkordata vplivala tudi na njihovo življenje in možnosti delovanja (zlasti v zvezi s kleriki, s pastoralnim delom v okviru župnij, z vodenjem vzgojno-izobraževalnih ustanov in $\mathrm{s}$ pripravo učiteljev). Izrecno je o redovnikih govoril člen 28 , v katerem so bile zagotovljene vloga višjih redovnih predstojnikov zunaj države, svoboda vzdrževanja stikov z njimi in pravica do opravljanja kanoničnih vizitacij, hkrati pa so bile poudarjene pravice krajevnih škofov v odnosu do redov, tudi potrebnost soglasja škofa za naselitev nove redovne skupnosti na njegovem ozemlju. Člena 11 in 14 sta samostanom pripisala dodatno nalogo: škofje bodo tja pošiljali duhovnike, ki bodo kaznovani zaradi kršenja cerkvene discipline ali zaradi drugega javnega prekrška. ${ }^{1}$ $\checkmark$ naslednjih letih se je večala vloga avstrijske škofovske konference, njenih odločitev in vplivov na redovne skupnosti. Novo obdobje je nastopilo, ko je bil konkordat odpovedan, čeprav so njegove določbe v največji meri veljale še naprej.

\section{Novi začetki na Slovenskem}

Medtem ko so jezuiti doživljali novo pomlad, so stare redovne skupnosti potrebovale več časa, da so se obnovile. Treba je bilo na novo organizirati skupnosti, ki so preživele, in postaviti materialne možnosti za njihovo skupno življenje. Papež Pij VII. (papež 1800-1823, član benediktinske skupnosti) se je takoj po vrnitvi v Rim posvetil urejanju pravnega položaja redovnih ustanov in je $v$ ta namen ustanovil poseben urad; delo je nadaljeval Leon XII. (papež 1823-1829) (Martina 1995, 108-109). V Avstriji je obnavljanje starih redov mogoče spremljati šele od zadnje četrtine 19. stoletja dalje, pri tem pa so imele pomemben vpliv politične okoliščine v drugih državah. Od teh skupnosti so se naselili trapisti v Rajhenburgu (1881), cistercijani v Stični (1898), kartuzijani v Pleterjah (1899). Iz prejšnjega stoletja so

Prim. izvirno (latinsko) besedilo konkordata: Zgodnja danica 8, št. 47 (1855); slovenski prevod je bil objavljen: Zgodnja danica 9, št. 9 (1856). To je bila seveda pomembna mednarodna listina, ki je dala temelje nadaljnjemu delovanju cerkvenih ustanov v monarhiji, zato je konkordat objavila tudi Zgodnja danica, drugače namenjena bolj širokemu krogu bralcev. 
v slovenskem prostoru ostale uršulinke (od 1702 v Ljubljani, od 1782 v Škofji Loki) (Kogoj 1982). Od preganjanih ženskih skupnosti so se na Slovensko naselile karmeličanke (1885, Selo pri Ljubljani) in magdalenke (1885, Studenice). V drugih delih Evrope so se starejše skupnosti obnavljale že od srede stoletja dalje. Če je za mendikantske skupnosti v velikem delu Evrope mogoče reči, da so iz obdobja revolucije izšle oslabljene - v nekaterih deželah (Francija, Belgija, Nemčija, Italija) je večina izginila, drugod (Španija, ruski del Poljske) so bile odrezane od osrednjega vodstva in povsem odvisne od državnih oblasti -, lahko vsaj za manjše brate (drugače kakor npr. dominikanci) $v$ habsburški monarhiji ugotovimo, da se jim je uspelo v veliki meri ohraniti, čeprav so pritisk državnih oblasti in voditeljev škofij, ki so bili navdušeni za razsvetljenske ideje, čutili na vsakem koraku ( $v$ resnici so morali zapustiti samo Sveto goro pri Gorici in Solkan, a so se preselili v minoritski samostan v Gorici). Veliko močneje so posledice čutili konventualci in kapucini, še najbolj pa klarise, ki so iz slovenskega prostora izginile za skoraj dvesto let. Oblike pastoralnega dela, ki so jih manjši bratje prevzeli predtem, so jim pomagale, da so preživeli in delo nadaljevali (Wolf 1871).

Če je bilo obnavljanje starih redov težavno in zahtevno, pa lahko vse od začetka 19. stoletja dalje spremljamo izreden razvoj sodobnih in časovnim potrebam bolj prilagojenih novih redov. Ti so doživeli razcvet, ki ga $v$ starih ureditvah niso poznali. Govorimo predvsem o različnih ženskih in v manjši meri o moških skupnostih, ki so prevzemale osrednje mesto na področju karitativno-socialnega in zdravstvenega dela in na vzgojno-izobraževalnem področju. Mnoge med njimi niso presegle škofijskih meja. Druge so postali nosilke dela Cerkve na omenjenih področjih in so se ustalile na vseh kontinentih. Od teh skupnosti so v slovenski prostor kmalu prišle hčere krščanske ljubezni (1843, Maribor), šolske sestre iz Eggenberga (1864, Maribor), šolske sestre de Notre-Dame (1886, Šmihel pri Novem mestu) in križniške sestre (1899, Ormož). Nove začetke imajo na Slovenskem skupnosti mariborskih šolskih sester (1869, Maribor) in Marijinih sester čudodelne svetinje (1878, Ljubljana), ki so prav tako zaživele svoj poklic na omenjenih področjih. Med moškimi skupnostmi se je na novo naselila misijonska družba lazaristov (1852, Celje). Te skupnosti niso bile obremenjene s preteklostjo in jim ni bilo treba opravičevati povezanosti s politično ureditvijo ali navezanosti na gospodarsko premoženje in v prejšnjih stoletjih vzpostavljenih gospodarskih odnosov.

Cerkev na Slovenskem, škofije, župnije in tudi redovne skupnosti je tako na začetku 19. stoletja zaznamovala vrsta družbenih in cerkvenopolitičnih posledic dogajanja v prejšnjem stoletju. Z nastopom novega stoletja niso bile odpravljene razmere, ki jih je vzpostavila politika državnega cerkvenstva in notranjecerkveni tokovi s konca 18. stoletja. Čutile so se tudi posledice kratkega obdobja vladanja Napoleona nad slovenskim prostorom. Tako škofje kakor duhovniki in verniki so čutili, da so se stvari resda spreminjale, a da se je duh časa, ki sta ga v dolgih letih vladanja vzpostavila vladarja Marija Terezija in Jožef II., utrdil in še ohranjal; posledice niso izginile $s$ smrtjo obeh vladarjev. To se je čutilo tako $v$ odnosih med državo in Cerkvijo kakor v načinih cerkvenega delovanja in v praktičnem vsakodnevnem življenju, tako pri organiziranju izobraževanja za duhovniške kandidate 
kakor pri podeljevanju zakramentov. Delovanje cerkvenih ustanov, uprava cerkvenega premoženja, odnosi med političnimi in cerkvenimi oblastmi, javni pomen nosilcev cerkvenih služb - vse je bilo še vedno v luči cerkvenih predpisov, ki so bili sprejeti $v$ času omenjenih dveh vladarjev. Le postopoma so se stvari začenjale spreminjati od druge četrtine 19. stoletja dalje, pri tem pa so imeli pomemben delež prav člani skupnosti manjših bratov, ki so skrb za ohranjanje pravovernosti in urejenega cerkvenega življenja izražali prek spisov, pridigarske dejavnosti, obnavljanja cerkvenih združenj in prek utrjevanja praktičnega verskega življenja na individualnem in na skupnostnem področju. Pri tem sta jim, kljub notranjim napetostim in posegom osrednjega vodstva Cerkve v njihovo organiziranost, dajala močno oporo osrednje vodstvo redovne skupnosti in priznavanje učiteljskega mesta papeža. ${ }^{2}$

\section{V skupnosti manjših bratov}

Iz obdobja velikih napetosti med državo in Cerkvijo, ko so represivne ukrepe razsvetljensko usmerjenih vladarjev čutile zlasti redovne skupnosti, so manjši bratje frančiškani na Slovenskem izšli kot najmočnejša redovna skupnost in so takšno mesto ohranili skozi celotno 19. stoletje (leta 1810 so imeli 9 skupnosti, leta 1853 jih je bilo 12 in leta 1900 še 11). 19. stoletje ima v razvoju skupnosti sv. Frančiška poseben pomen tudi v luči urejanja odnosov med posameznimi skupnostmi, ki so se razvile $v$ teku stoletij in so se sklicevale na duha asiškega ubožca. Vedno močnejše so bile pobude, da bi dosegli večjo edinost in povezovanje tudi v organizacijskem smislu in da bi reformna prizadevanja postala skupni cilj vseh smeri. Odločilen za nadaljnje dogajanje je bil generalni kapitelj leta 1895, na katerem je bila po dolgih razpravah in posegih Svetega sedeža skoraj enoglasno (100 glasov za, 8 proti) sprejeta odločitev o združitvi. Maja 1897 so bile sprejete skupne konstitucije (Leonove konstitucije) in še istega leta je takšno odločitev podprl tudi papež Leon XIII., drugače znan po svojih pobudah, da bi dosegli večje povezovanje (centralizacijo) različnih redovnih skupnosti. Skupno ime je postalo red manjših bratov, v slovenskem prostoru pa se je uveljavil izraz frančiškani. V samostanih hrvaško-kranjske province je prevladovala enotna (strožja reformatorska) smer že predtem (Škofljanec 2000, 28; Bahčič 2007, 177-184).

Kakor v prejšnjem obdobju so se dobršen del stoletja zavzemali za odpravo posledic rigorizma in janzenizma v praktičnem verskem življenju, na teološkem področju in v ravnanju Cerkve nasploh; o tem obširno govori Čebulj (Čebulj 1922).

2 Od obilne literature, ki obravnava zgodovino frančiškanske skupnosti na Slovenskem, omenjamo delo Regalata Čebulja: Janzenizem na Slovenskem in frančiškani. Delo je bilo predstavljeno kot inavguralna disertacija na teološki fakulteti v Zagrebu. Izšlo je v Ljubljani leta 1922, 63 str. Več let (1924-1930) je v reviji Cvetje z vrtov sv. Frančiška izhajal spis Angelika Tominca Pregled zgodovine frančiškanov med Slovenci. Robert Bahčič je pripravil monografijo Čudež, ki traja 800 let: Zgodovina Frančiškove karizme $v$ svetu in pri nas (Ljubljana, 2007). V zadnjih letih so izšle predvsem monografije, ki so predstavile posamezne samostane ali osebnosti iz zgodovine frančiškanske skupnosti na Slovenskem. Naš prispevek se omejuje na frančiškanske ustanove, ki so v 19. stoletju delovale v današnjem slovenskem prostoru. 
Zlasti pri podeljevanju zakramentov spovedi in obhajila in v ravnanju duhovnikov na tem področju so se čutile posledice še več desetletij 19. stoletja, to je, vse do takrat, dokler so v pastoralnem delovanju Cerkve imeli vodilna mesta duhovniki, ki so izšli iz šol, kakršne so v prejšnjem obdobju organizirali janzenistično usmerjeni državni uradniki in njihovi cerkveni sodelavci. Med avtorji, ki so bili na Slovenskem znani po ohranjanju takšnih idej, se najpogosteje omenjajo: Jurij Japelj, Janez Traven, Jožef Škrinjar, Jožef Rihar, Modest Šraj, Matevž Wolf in Gašper Švab. Med duhovniki v župnijah, ki so izstopali po svoji strogosti in so se zapisali v slovensko duhovno in kulturno zgodovino, pa so: Jurij Pavšek, Jožef Dagarin, Vojska, Mihael Mušič, J. Stanonik, novomeški prošt Nikolaj Peršič, Filip Grošel in drugi (Dolinar 1991, 169-170; Pokorn 1908). Teološki pogledi in ravnanje manjših bratov so bili v nasprotju z gornjimi stališči. V skladu s teološkim izročilom skupnosti so poudarjali pomen prizadevanja, trdnega sklepa in osebne odločenosti posameznika, da vztraja v dobrem. Pomembno mesto v številnih škofijah jim je omogočalo, da so kljub prevladujočim drugačnim načelom lahko nadaljevali svoje delo in ga utemeljevali z zdravo pastoralno izkušnjo. Delo proti janzenističnim idejam in napačni verski praksi so frančiškani nadaljevali še daleč v 19. stoletje, saj so se takšne ideje ohranjale tako med verniki kakor med duhovščino.

Že v času uveljavljanja načel, kakršne je v delovanju ljubljanske škofije postavljal škof Janez K. Herberstein, so bili manjši bratje znani po svojem nasprotovanju teološkim avtorjem in njihovim spisom, ki so resda imeli odobritev državnih ustanov, a so bili znani po zagovarjanju janzenističnih načel in zakramentalne prakse. Reakcije škofa Herbersteina kažejo, da so mu bila znana ravnanja frančiškanskih predstojnikov in to, da niso odobravali avtorjev, ki jih je on priporočal in so jih v teoloških šolah uporabljali po državnem naročilu. Skupina teološko dobro izobraženih članov je ljubljanskim manjšim bratom omogočila, da so lahko suvereno zavračali skrajne ideje ter svoje učenje in ravnanje utemeljevali s cerkvenim izročilom in z uglednimi avtorji preteklih stoletij. Že v času razcveta janzenizma in učiteljskega delovanja škofa Janeza K. Herbersteina so bili frančiškanski teologi pozorni na njegovo učenje in so ga zavračali z izbranimi teološkimi razpravami in publikacijami. Med avtorji velja omeniti vsaj dva, ki sta bila obravnavana na več mestih: lektor in poznejši provincial p. Oto Sprug $(+1781)$ (Čebulj 1922, 46-49) ${ }^{3}$ in lektor bogoslovja in večkratni provincial p. Kastul Weibl (+1805) (Čebulj 1922, 50-54). ${ }^{4}$ To je bilo načrtno in sistematično spremljanje tovrstnih idej, njihovo obravnavanje in zavračanje. Znanstveno obravnavo teh področij, njihovo usklajevanje s tradicionalnim katoliškem učenjem in načrtno zavračanje lahko ocenimo kot prispevek frančiškanov na Slovenskem pri razvoju teološke misli, pri skrbi za ohranjanje teološke pravovernosti in v prizadevanju za poglobljeno praktično versko življenje, ki je imelo svoje temelje prav v tradicionalnem učenju.

Sprug se je odlikoval kot lektor v frančiškanski bogoslovni šoli in kot njen vodja. Svojo pozornost je v spisih namenjal predvsem vprašanjem janzenizma in galikanizma in delu za preprečitev njunega vpliva na Slovenskem (SBL 3. 427-428).

4 Weibl je poučeval na frančiškanskih šolah, tudi filozofijo in teologijo, predvsem pa je opravljal pomembne predstojniške službe. Izkazal se je kot odločen nasprotnik janzenizma in jožefinizma. V praktičnem verskem življenju je poudarjal pomen ljudskih pobožnosti, zlasti tistih, ki so bile pomembna sestavina frančiškanske duhovnosti, to je: križev pot in češčenje sv. Frančiška (SBL 4, 669-671). 
Ni pretirano reči, da so neke vrste obračun z idejnimi in duhovnimi tokovi prejšnjega časa v teku 19. stoletja opravili prav redovniki, med njimi na prvem mestu frančiškani, takrat najbolj številna skupnost, znani po svojem nasprotovanju janzenizmu in po zdravi distanci, ki so jo znali ohranjati tako do cerkvenih kakor do posvetnih oblasti, ves čas tudi proti njihovemu poseganju na področja, ki jim niso bila podrejena. "Ravno v tem redu je vzrasel janzenizmu na Slovenskem najhujši nasprotnik, ki ga je pobijal ne samo na znanstvenem polju, ampak še bolj v praktičnem pastirstvu. Ne samo, da je bil ta red najbolj razširjen in nekako zrasel s slovenskim ljudstvom, mogel je tudi ravno potom tretjega reda svoje ideje najlaže širiti, « je ugotovil R. Čebulj v svoji raziskavi. (Čebulj 1922, 42)

\section{Uveljavljanje novih idej}

V teku stoletja so se tako v življenju Cerkve kakor v življenju njenih posameznih ustanov, tudi pri manjših bratih, zgodile pomembne in daljnoročne spremembe. Postopoma so se na mnogih področjih cerkvenega življenja uveljavljale nove ideje, ki so bile sad idejnih in duhovnih tokov razsvetljenstva in so se razširjale skupaj $z$ idejami francoske revolucije. Nov val idej sta $v$ evropsko družbo in $v$ njeno gledanje na mesto religije $v$ javnem življenju prinesla proces sekularizacije in $v$ neki določeni meri dogajanje, na katero je vplival Kulturkampf $\vee$ nemških deželah; odmeve tega dogajanja je bilo čutiti tudi v Avstriji. $V$ skupnostih, medsebojnih odnosih, redovnem izobraževanju in v vzgoji so se tako kazali vplivi iz širšega družbenega okolja in dogajanja v Cerkvi na evropski ravni.

Te spremembe so se zgodile na notranje redovnem področju, se pravi: v organiziranosti. V skladu z dvornim dekretom z dne 9. februarja 1783 so morali biti samostani organizirani v okviru vsakega dežele, brez povezav $z$ drugimi pokrajinami (Tominec 1926, 47-48). Posledice so čutili zlasti člani slovenske frančiškanske province, ki je bila razdeljena na dve: na hrvaško-primorsko (dobila je ime kustodija) in na kranjsko provinco sv. Križa. Takrat so se prvič močneje pokazale potrebe po ovrednotenju nacionalne pripadnosti vsakega sobrata. Voditelj kranjske province je namreč v svojo skupnost z naklonjenostjo sprejemal člane hrvaško-primorske skupnosti, rojene na Kranjskem, katerim je dvorni dekret dovoljeval, da so se vrnili v domačo provinco. Kakor poročajo samostanske kronike, pa je voditelj hrvaško-primorske province narodnost zelo poudarjal in od članov, ki so prihajali s Kranjske, zahteval pisno obljubo, da bodo ostali pod njegovo oblastjo (51). Celotno 19. stoletje so bile frančiškanske skupnosti, ki so tvorile narodnostno mešane skupnosti, vsaj nekoliko zaznamovane z napetostmi, ki so izvirale iz jezikovnih in kulturnih razlik; ta razsežnost je dobila poseben pomen, potem ko se je od sredine stoletja dalje razmahnilo narodnostno gibanje pri vseh narodih, ki so sestavljali podonavsko monarhijo.

Prodirale so ideje o novi vlogi in liku redovnega predstojnika: predstojniki so morali biti v službi države in svoje skupnosti vzgajati tako, da bodo v krajevnem škofu in v predstavnikih države videli najvišjo oblast tudi na cerkvenem področju. Posebna odredba dvorne verske komisije $z$ dne 30. novembra 1784 je določala, 
da si od tedaj dalje vsak samostan sam voli svojega predstojnika. „Provincijal ima le pravico, volitve potrditi ali pa odreči potrditev, če oseba ni primerna. Volitve se udeleže vsi redovniki, ki imajo že obljube izvzevši brate lajike. Izvoljeni smejo biti le redovni mašniki.« (47) Volitve so bile veljavne, če se je izkazala absolutna večina, če pa tudi tretje volitve niso bile uspešne, je bil izvoljen tisti, ki je dobil največ glasov. Redovniki so morali imeti volitve vsako tretje leto zadnje tri dni v decembru. Po izvolitvi si je predstojnik izbral sodelavce, ki so prevzeli ustaljene samostanske službe. Samostanski predstojniki so nato vsakih šest let volili provinciala. $S$ tem je bil odpravljen definitorij, ki je do tedaj imel odločilno vlogo pri določanju nosilcev služb znotraj province. Volitve so morali potrditi politične oblasti in krajevni škof. Za volitve provincialnih predstojnikov so morali imeli dovoljenje krajevnega škofa in vlade. Dan volitev je bilo treba poprej sporočili na oba naslova. Kanonična vizitacija samostanov je bila kot redna oblika skrbi za disciplino v skupnostih odpravljena; provinciali so imeli pravico do vizitacije le takrat, ko so v skupnosti nastali neredi. Čeprav so tako cerkvene kakor politične oblasti skrbele, da so bili tovrstni odloki redno in javno predstavljeni, so redovne skupnosti skušale ohranjati stare načine urejanja notranjih razmer, kakor je bilo v skladu z njihovimi lastnimi pravili.

Drugače kakor v času jožefinskih in cerkvenopolitičnih idej v 18. stoletju je bil po smrti Jožefa II. in zlasti od vladanja Franca II. dalje predstojnik krajevne skupnosti pri sprejemanju svojih odločitev manj odvisen od državnih oziroma političnih oblasti in od vsakokratnega krajevnega škofa. Spet se je uveljavljala vloga provincialnih kapitljev, pa tudi volitve predstojnikov in določanje bratov za posamezne službe (Ožinger 2000, 212). Če so predtem veljala načela, da morajo biti vse redovne skupnosti podrejene krajevnemu škofu in je bilo de facto odpravljeno načelo eksemptnosti (za škofa J. K. Herbersteina "zastarela rana cerkvene discipline«), so se od začetka 19. stoletja dalje s težavo uveljavljala načela, značilna za prejšnja stoletja, načela, ki so postala sestavni del ravnanja Cerkve in njenih ustanov. Mnogi škofje, med njimi J. K. Herberstein, so posegali v povsem interne zadeve redovnih skupnosti, njihovo disciplino, navade, volitve predstojnikov, medsebojne odnose. Glede na državne predpise, ki so redovnike podredili jurisdikciji škofov, mu je ta pravica resda pripadala, vendarle je dobro vedel, da »so se frančiškani temu uklonili le v toliko, v kolikor so se vsled razmer morali« (Čebulj 1922, 23). Kljub zagroženim posledicam so še naprej ohranjali stike z Rimom in z vrhovnim vodstvom skupnosti; cesarska odredba z dne 24. marca 1781 je resda prekinila vse stike redovnim skupnostim v Avstriji z njihovimi vrhovnimi predstojniki, ki so prebivali zunaj monarhije. Od leta 1792 dalje so redovne skupnosti spet smele sprejemati novince. Dvorni odlok z dne 2. aprila 1802 je zopet dovolil volitve provincialov in drugih redovnih predstojnikov na tri leta, kakor je bilo v skladu s pravili. Znova so bile dovoljene redne kanonične vizitacije provincialov, za to ni bilo potrebno dovoljenje cerkvenih ali državnih oblasti (Tominec 1926, 48). Pomembno sredstvo prenavljanja razmer v skupnostih so spet postale okrožnice, ki so jih provinciali razpošiljali na za to določeni čas (Ožinger 2000, 213). V polni meri pa je bilo to mogoče šele z uveljavitvijo novega konkordata leta 1855 . Z njim so 
bile odpravljene vse ovire za svobodno komunikacijo med redovnimi predstojniki $v$ monarhiji in osrednjim vodstvom Cerkve v Rimu. Kanonične vizitacije redovnih skupnosti so sredi stoletja še vedno opravljali škofje (leta 1852 je papež Pij IX. imenoval za apostolskega vizitatorja redovnikov v Avstriji kardinala Feliksa Schwarzenberga), od konca petdesetih let dalje pa njeni člani oziroma člani drugih provinc (Škofljanec 2000, 62).

Za prenovo redovniškega življenja se je kot sovizitator samostanov $v$ avstrijskem delu monarhije zavzel lavantinski škof Anton Martin Slomšek, ki je redove obiskal $v$ letu 1856/1857. Poleg splošnih ugotovitev in navodil, veljavnih za vse redovne skupnosti, je dal nekaj izvirnih za benediktince, za kapucine in za frančiškane. Pri skupnostih manjših bratov je ugotavljal kršenje klavzure, upravljanje materialnih dobrin na način, ki je bil v nasprotju z redovnimi pravili, neustrezno skrb predstojnikov za redovne brate in njihovo pomanjkljivo duhovno oskrbo in druge pomanjkljivosti. Pri tem je pokazal dobro poznanje razmer v obiskanih skupnostih in nemoč krajevnih predstojnikov, da bi v skupnosti uvedli red; zato je predlagal, da bi vizitatorji prihajali iz drugih provinc. Za zagotavljanja reformnih prizadevanj je dal predlog, da bi samostani v Avstriji imeli redne vizitacije na tri do sedem let. „Obnovo redovnega duha in življenja je Slomšek videl $v$ vračanju k virom ustanoviteljev, v izpolnjevanju obljube uboštva, $v$ skupni molitvi in $v$ skrbi za redovne poklice ter $v$ redovni disciplini, ki se kaže na zunaj in na znotraj $v$ redovni skupnosti in v življenju vsakega posameznika." (Papež 1983, 83) Ugotovitve se niso dosti razlikovale od tistih, na katere so že desetletja predtem v svojih okrožnicah opozarjali in jih spodbujali provinciali: o samostanski klavzuri in obiskih zunanjih oseb, o izhodih iz samostana in redovni obleki, o molitvenih obveznostih do rajnih sobratov in vernikov, o pobožnostih v samostanu (sveta maša, meditacija, duhovno branje), o skrbi za izobraževanje klerikov in bratov, o upravljanju samostanskega premoženja in o drugih razsežnostih življenja skupnosti (Ožinger 2000, 213).

$\checkmark$ času francoske oblasti nad slovenskimi deželami in med delovanjem llirskih provinc so se morali novi ureditvi prilagoditi tudi frančiškani. Maršal Marmont je leta 1810 takratnemu provincialu kranjske province Antonu Jevnikarju naročil, da je združil v eno provinco vse samostane, ki so ležali na ozemlju llirskih provinc; odločitev je bila sprejeta dne 8 . avgusta 1810 . Nova struktura se je imenovala llirska provinca sv. Križa. Zunaj je ostal samostan v Kranjcu in samostana v Brežicah in v Nazarjah; ta dva sta pripadla graški provinci. Matični provinci sta bila ponovno pridružena po odhodu Francozov $z$ dvornim dekretom $z$ dne 23. novembra 1815. Poleg ukrepov, ki so zadevali vsakodnevno življenje ljudi, so francoske oblasti omejevale število novomašnikov; provincial je moral imeti za vsakega novega duhovnika izrecno dovoljenje Napoleona ali ministra za verske zadeve. Vojaški obvezniki so postali vsi člani redovnih skupnosti, ki še niso imeli subdiakonata. Odlok francoskih oblasti z dne 17. septembra 1813, po katerem bi morali biti v Ilirskih provincah ukinjeni vsi samostani (moški in ženski), ni bil uresničen, ker je bilo prej konec francoske oblasti na slovenskih tleh (Tominec 1926, 49).

Skupnosti so se morale soočati s splošnimi problemi, ki so bili značilni za kleriški stan v tem času: navsezadnje so bili tudi manjši bratje vse bolj kleriška ustanova. 
Svojevrstni problemi so bili z brati laiki, ki so bili tesno vpeti v gospodarstvo vsakega samostana, in še posebno z okoljem, v katerem je samostan ležal. V vrstah klerikov so se kazale različne razvade, ki so postale pomembna skrb voditeljev škofij in predmet kanoničnih vizitacij. Pri tem govorimo o poudarjenem sprejemanju odločitev brez soglasja pristojnih cerkvenih oblasti, o samovoljnosti pri upravljanju cerkvenega premoženja, o neupoštevanju navodil škofov glede pastoralnih pristopov k posameznim skupinam vernikov in o osebnih slabostih, ki so kot posledica tega manjšale ugled ne le posameznikov, temveč stanu kot takšnega (pogosti primeri vdanosti pijači, kršenje celibata in druge razvade). Vizitacija leta 1871, ki jo je opravil član tirolske province Evzebij Schmidt, je pokazala stanje skupnosti. »Nekateri samostani so imeli posesti in so zato vzdrževali hlapce in živino, posamezni bratje so kljub državni finančni podpori hodili na bero, samostanski predstojniki niso primerno skrbeli za hrano in obleko sobratov, le en samostan je imel apostolskega sindika. Zanemarjeno je bilo skupno življenje, saj so le v štirih samostanih skupaj molili brevir, meditacijo so imeli trikrat tedensko po četrt ure, polovica bratov ni nosila tonzure, « ugotovitve povzema J. Škofljanec (Škofljanec 2000, 62).

Prav v segmentu gospodarskega poslovanja in odnosa do materialnih dobrin se je velikokrat najbolj pokazala vpetost samostanske skupnosti v kak kraj in krajevno skupnost. Ne samo s cerkvijo in samostanskim poslopjem, temveč tudi z življenjem članov skupnosti je red vplival na življenje ljudi in na njihovo vernost. Tako ali drugače se je dogajanje v samostanu poznalo v odnosu, ki so ga do njega imeli ljudje in kot posledica tega do Cerkve nasploh. Monografske objave o posameznih samostanih manjših bratov na Slovenskem v zadnjih letih vsebujejo tudi ta vidik. Med vsemi velja omeniti zbornik razprav ob tristoletnici brežiških frančiškanov, ki na to opozarja že s svojim naslovom $S$ patri smo si bili dobri. ${ }^{5}$ Ob tako zastavljenih monografskih študijah je mogoče bolj poglobljeno govoriti o vplivu posameznih redov ali redovnih skupnosti na širšo družbo ali pokrajino. ${ }^{6}$

\section{Nove naloge manjših bratov na izobraževalnem področju}

Slovensko družbo konec 18. in 19. stoletja so zaznamovale številne spremembe na vzgojno-izobraževalnem področju, pri katerih so bile udeležene tudi cerkvene ustanove. Zakonodaja, ki sta jo sprejela Marija Terezija in Jožef II., je resda veljala, a se je dejansko le malo spremenilo, kajti ni bilo učiteljev in ne šolskih prostorov. Sredstva, ki jih je država namenjala za izobraževanje, so bila negotova; premoženje šolskega sklada, ki je nastalo iz premoženja ukinjenih bratovščin, je bilo kmalu zapra-

Prim. S patri smo si bili dobri: Tri stoletja brežiških frančiškanov: zbornik znanstvenih razprav, ur. Jože Škofljanec, Brežiške študije 4 (Krško-Ljubljana, 2013).

$6 \quad$ V omenjenem delu je s svojim prispevkom obširneje predstavil ta vidik M. Ambrožič: Življenje in dejavnosti brežiških frančiškanov v 19. stoletju, str. 89-121. Pri tem je posebej opozoril na odgovornost, ki so jo za takšno stanje imeli vsakokratni predstojniki provinc; navsezadnje so prav predstojniki odločali, kdo bo prebival in deloval v katerem od samostanov. 
vljeno. Zato je bilo sistematično izobraževanje še vedno $v$ veliki meri v rokah cerkvenih ustanov in odvisno od njihovih sredstev. Skupnost manjših bratov je imela pomembno mesto na izobraževalnem področju, kajti v skrbi za izobraževanje so videli dobro možnost za službo ljudem in za dvig kulturne ravni ljudstva, med katerim so delovali. Če ne poudarjamo posebej večanja števila ljudskih šol in gimnazij, skrbi za opremo učilnic in priprave raznih zbirk, je s svojim načrtnim in sistematičnim delom za izobrazbo strokovno in metodično pripravljenih učiteljev skupnost manjših bratov bistveno prispevala $k$ dvigu ravni oziroma kakovosti šolstva na Slovenskem. Pri tem jih je resda spodbujala in $\mathrm{k}$ temu zavezovala državna zakonodaja, vendar je bilo vsakokratno vodstvo zadosti razgledano, da je v pospeševanju kakovosti videlo pomembno razsežnost svojega dela. To je pomagalo, da so se manjši bratje trudili za profesionalizacijo šolskega dela, za uveljavljanje lika učitelja, ki je živel za šolo in mu je bil šolski pouk najpomembnejša oblika delovanja. Takšen učitelj je imel možnost osebnega strokovnega razvoja in na voljo sredstva, da je razvijal svoj šolski predmet. V Novem mestu so na prošnjo meščanov prevzeli skrb za gimnazijo (1746) in za ljudsko šolo (1778); na obeh so v 19. stoletju povečali možnosti (Tominec 1927, 20). Ker ni bilo državnih učnih načrtov za gimnazije, so morali za to skrbeti frančiškani sami. Pri svojem učiteljskem delu so uporabljali slovenski jezik. Frančiškanska gimnazija v Novem mestu je delovala kot zasebna šola do leta 1870 , ko je postala državna. Kot učitelji so lahko ostali tisti manjši bratje, ki so imeli ustrezne izpite. Delo so tako nadaljevali tudi po spremembah šolske zakonodaje. "Kakor gimnazija tako je bila tudi ljudska šola prava pastorka $v$ očeh občine in države. Šolsko poslopje, nastanjena je bila še vedno v stari gimnaziji, je bilo zanemarjeno, prostori nezadostni in nezdravi, ker nihče ni hotel nositi stroškov za popravo. Plača učiteljev je bila smešno nizka in vrhu tega je šolski svet delal frančiškanom mnogo sitnosti, " ugotavlja zgodovinar skupnosti A. Tominec (21-22).

Delo v ljudski (nato glavni) šoli je sodilo med vplivne oblike navzočnosti v Kamniku in to jim je pomagalo, da samostan ni bil ukinjen v času jožefinskih ukrepov. Novi prostori, zgrajeni po požaru leta 1804, so omogočili boljše delo, ki so ga v glavni šoli frančiškani prevzeli v celoti (frančiškani so delovali kot edini nosilci pouka na deški šoli od leta 1801 do leta 1882). Sredi stoletja je bila šola štirirazrednica, pridružena ji je bila nedeljska šola z dvema oddelkoma (Tominec 1927, 25; Šuštar 1993, 77-101). Frančiškanski samostan v Nazarjah je zagotavljal prostor novoustanovljeni šoli od leta 1786 dalje. Naloge učitelja je opravljal eden od članov skupnosti. Ta trivialka je bila prva in najstarejša šola v celotnem gornjegrajskem okraju, obiskovali so jo tako dečki kakor deklice. Za vsa področja njenega delovanja so morali skrbeti frančiškani sami (Tominec 1927, 51). Od leta 1780 dalje je ljudska šola delovala tudi v samostanu v Brežicah (in uporabljala samostanske prostore do leta 1804); prvo desetletje je imela tri razrede, nato do leta 1829 dva, od tedaj dalje ponovno tri. Sredi 19. stoletja (1858) je imela štiri razrede. Potem ko je leta 1804 vodstvo župnije prevzel škofijski duhovnik, so frančiškani ohranili vodstvo šole. Manjši bratje so na ljudski šoli v Brežicah delovali do leta 1871; takrat so vodstvo šole prevzeli zunanji učitelji (Tominec 1927, 54; Šuštar 2013, 321-352). 
Posebno področje je bilo organiziranje izobraževanja za kandidate in člane skupnosti. Frančiškanska provinca sv. Križa je imela svojo teološko izobraževalno ustanovo vse od leta 1593 dalje. Zaradi dvornega dekreta cesarja Jožefa II. z dne 30. marca 1783 je ta šola morala prenehati delovati - podobno kakor škofijska semenišča in vse samostanske šole nasploh. Vstop v samostan je bil mogoč le, če je nekdo poprej opravil študij v generalnem semenišču in bil šest let v praktičnem župnijskem pastoralnem delu. Nekatere oblike izobraževanja znotraj skupnosti pa so frančiškani ohranili ves čas. Tu so imeli možnost, da so svoje kandidate pripravljali v duhu svojega duhovnega izročila, tudi v večjem poudarjanju mesta, ki ga je v Cerkvi imel rimski škof, v poudarjanju človekovega osebnega zaupanja v Boga in ljubezni do njega. V svojem učenju so izhajali iz dobrega poznavanja človeške narave, iz nagnjenosti človeka k slabemu in hkrati iz slabosti človeške volje; vse to jih je povezovalo z ljudmi, med duhovniki in pri škofu J. K. Herbersteinu pa jim je prineslo sloves laksistov.

Čeprav prva prizadevanja za ustanovitev svoje lastne teološke šole v Ljubljani segajo že v leto 1805, je bila frančiškanska filozofska in teološka šola v ljubljanskem samostanu ponovno dovoljena s cesarskim odlokom dne 26. septembra 1817, potem ko so kandidati za duhovništvo v poprejšnjem obdobju več let študirali zasebno pod vodstvom domačih učiteljev in izpite opravljali na ljubljanskem liceju ali pa na isti ustanovi tudi obiskovali predavanja (Zschokke 1894, 1190-1197). Od tedaj dalje so frančiškanski bogoslovni lektorji z besedo in spisi skozi celotno stoletje uveljavljali ustaljeno cerkveno učenje in mlade duhovnike uvajali v takšne oblike pastoralnega delovanja, ki so postopoma odpravljale posledice deformacij iz prejšnjega obdobja. Leta 1821 so v samostan na Kostanjevici pri Gorici preselili filozofski študij in prva dva letnika teologije; tretji in četrti letnik sta ostala v Ljubljani (Špelič 2010, 216-220). Predavanja so imeli možnost poslušati tudi člani drugih frančiškanskih provinc in člani skupnosti usmiljenih bratov. Po letu 1885 so bile nekatere oblike bogoslovnega študija organizirane tudi v samostanu v Kamniku.

Pomembno mesto na vzgojno-izobraževalnem področju - frančiškani so ga imeli vse do propada habsburške države - jim je narekovalo skrb za sistematično pripravo duhovnikov, ki so prevzemali naloge v osnovnih (trivialnih, glavnih, normalnih) šolah in na gimnazijah. $V$ ta namen so navadno uporabljali enega od samostanov, v katerem so prebivali mladi člani reda in njihovi učitelji. Z dovoljenjem cesarja Franca I. z dne 5. novembra 1821 je na Kostanjevici pri Gorici začela delovati frančiškanska višja gimnazija s filozofskimi predmeti in dve leti zatem še prva dva letnika bogoslovja, »kar je bilo velike važnosti ne le za red in njegove potrebe, ampak tudi za vzdrževanje treh gimnazij, ki jih je tisti čas vzdrževala provincija sv. Križa (Tominec 1928, 91). To so bile javne gimnazije v Karlovcu, v Pazinu in v Novem mestu. Spričevala, ki jih je izdajala šola na Kostanjevici, so imela javno veljavo. Prva generacija učiteljev si je strokovne kvalifikacije pridobila v Zagrebu. Z večanjem števila učiteljev in mladih frančiškanov je Kostanjevica dobivala vedno večji pomen za celotno provinco in postajala hkrati pomembno duhovno središče v neposredni soseščini Gorice. Modroslovna šola, ki so jo na Kostanjevici vodili slovenski frančiškani, je delovala vse do prve svetovne vojne (Tominec 1930, 148- 
149). Država si je pridržala pravico do nadzorovanja delovanja te zasebne šole. Kot ravnatelj je nastopal goriški nadškof, ki je sam ali po svojem komisarju nadzoroval delo šole in bil navzoč pri izpitih (149). Tako se je na Kostanjevici usposobilo večje število slovenskih frančiškanov, ki so nato prevzemali odgovornosti v raznih samostanih in župnijah in po različnih šolah. Skrb za izobraževanje in pripravo dobrih učiteljev na vseh ravneh izobraževanja, ki ga je imela provinca, pa je vodstvu province narekovala, da so posamezniki študirali tudi na javnih univerzah, na katerih so dosegali akademske nazive in bili s tem usposobljeni za prevzemanje nalog $\mathrm{v}$ svojih lastnih šolah.

\section{Na področju praktičnega verskega življenja}

Konec 18. in začetek 19. stoletja sta bila znana po zavračanju oblik pobožnosti, ki so temeljile na doživljanju in na večji vlogi človekovih čustev in so poudarjale pomen razumarskega ravnanja tudi v praktičnem verskem življenju. Zato je bilo veliko nasprotovanja oblikam pobožnosti, ki so imele prve značilnosti in so bile priljubljene zlasti v okoljih, kjer do delovali manjši bratje. Med takšne oblike, ki so pritegovale posebno pozornost novih duhovnih/idejnih struj, so bile: pobožnost križevega pota, podeljevanje odpustkov, blagoslavljanje podob in križev, molitev rožnega venca, delitev lističev sv. Luka, podeljevanje pisem afiliacije, češčenje pred izpostavljenim Najsvetejšim, devetdnevnice v čast božji Materi ob različnih praznikih, zlasti pred praznikom Brezmadežne, češčenje ran sv. Frančiška in drugo. Duhovniki, ki so priporočali 40-urno pobožnost ali iskanje pomoči pri sv. Antonu Padovanskem, so izgubili pravico do pridiganja. Za ljubljanskega škofa J. K. Herbersteina je bilo posebno moteče podeljevanje odpustkov ob prazniku sv. Porciunkule (Čebulj 1922, 17-20). Čeprav so manjši bratje predtem že pridobili soglasje pristojnih cerkvenih oblasti in so imeli stoletno izročilo, se je škof vendarle lotil te oblike pobožnosti in grozil s cerkvenimi sankcijami, če z njo ne bi prenehali. Ko jo je škof prepovedal, so se za pomoč zatekli k svetni oblasti. R. Čebulj je to dogajanje povzel z besedami: „Dejstvo, da so bili frančiškani prisiljeni v obrambo cerkvenih pobožnosti pomoči iskati pri svetni gosposki in to zoper škofa, ki bi bil moral iste pobožnosti že po svojem poklicu, ako ne braniti, pa jim vsaj ne nasprotovati, Herbersteina dovolj označuje." (20)

Marsikdaj so manjši bratje (enako tudi drugi redovniki, ki so preživeli čas jožefinskih represivnih ukrepov), kljub izrecni prepovedi, ohranjali te pobožnosti in tako pripomogli, da so se ohranile, podobno kakor so ohranjali bratovščinsko življenje (ukinjene so bile te pobožnosti leta 1784, premoženje pa je bilo dodeljeno šolskemu skladu). Tako so se v teku 19. stoletja počasi obnavljale stare oblike ljudskih pobožnosti in uveljavljale nove. V okoljih, kjer so delovali frančiškani, so bile v prejšnjem obdobju uveljavljene oblike združevanja vernikov predvsem tretji red in bratovščina pasu sv. Frančiška (uradno odobrena v letu 1585, v Avstriji ukinjena leta 1783), bratovščina sv. Antona in bratovščina karmelske Matere Božje. Člani bratovščine pasu sv. Frančiška so imeli v vsaki samostanski cerkvi svoj oltar sv. 
Frančiška, svoje lastno bandero, s katerim so se delovali v procesijah, in svojo nedeljo v mesecu, ko so se zbirali k molitvam (Furlan 1926, 26-27).

$\mathrm{V}$ teku 19. stoletja so bile postopoma obnovljene razne oblike cerkvenih združenj - zlasti pri organiziranju tretjega reda so imeli manjši bratje osrednje mesto. Obnovljene skupine so zaživele pri posameznih samostanih v teku stoletja. Leta 1815 je bila pri frančiškanih v Kamniku obnovljena bratovščina karmelske Matere Božje. Leta 1828 so frančiškani v samostanu Nazarje pripravili slovensko besedilo molitvenika za člane bratovščine sv. Rešnjega telesa, da so jim s tem dali pripomoček za tedensko molitev pred Najsvetejšim. ${ }^{7}$ Od srede stoletja dalje so nov razcvet doživljale različne skupine Marijinih družb, zlasti po letu 1854, ko je bila razglašena verska resnica o Marijinem brezmadežnem spočetju. Čeprav so posamezni škofje v prejšnjem obdobju ostro nasprotovali češčenju Jezusovega Srca, se je ohranilo in razširjalo prav s pomočjo zavzemanja redovnih skupnosti. Pri ljubljanskem samostanu je bila leta 1827 ustanovljena bratovščina Srca Jezusovega, ki je hitro pritegnila številne vernike in tudi nekatere duhovnike, da so pridobivali nove člane. ${ }^{8}$ Iz zapisnika članov je razvidno, da se je v dobrih dveh letih vpisalo blizu 3000 članov.

Z obnavljanjem romarskih središč se je pokazala potreba, da bi njihovo oskrbovanje prevzemale redovne skupnosti. Poleg ohranjanja skrbi za ugledna romarska središča, ki so bila v oskrbi frančiškanskih skupnosti že iz prejšnjega obdobja, so v teku stoletja prevzeli skrb še za nove. Tu mislimo predvsem na slovensko župnijo in cerkev Marije Matere milosti v Mariboru od leta 1864 dalje (Tominec 1927, 89; Heric 1894, 33-35), na Sveto Trojico v Slovenskih goricah od 1854 dalje (Tominec 1927, 92-93; Landergott 1904, 29ss.) in nazadnje na skrb za vedno pomembnejše Marijino romarsko središče na Brezjah (od 1898 dalje). Tja so resda že od leta 1894 dalje pošiljali v pomoč svoje duhovnike kot spovednike, zlasti ob večjih romarskih shodih. Leta 1811 so po odredbi francoskih oblasti frančiškani (pregnani s Svete Gore in so prebivali v Gorici od leta 1786 dalje) prevzeli nekdanji samostan karmeličanov na Kostanjevici pri Gorici, ki je hkrati z večanjem pomena kot grobnica članov rodbine Burbonov (in nekaterih drugih) od leta 1836 dalje večal svojo vlogo $v$ frančiškanski provinci zaradi filozofskega in teološkega študija, organiziranega v tem samostanu. Ob koncu obdobja, ki ga obravnavamo, to je: v letu 1900, so frančiškani ponovno prevzeli samostan s cerkvijo na Sveti Gori in široko zastavili obnovo zanemarjenega svetišča in romarskega doma.

Vedno večji pomen so dobivale nove oblike pastoralnega dela, ki jih je narekoval čas, pa tudi razmere v cerkvenih občestvih. Od druge polovice 19 . stoletja dalje so bili organizirani ljudski misijoni. Na njih so pridigarji imeli možnost, da so utrjevali vero ljudi na splošno, a tudi obnavljali oblike pobožnosti, ki so bile v prejšnjem času preganjane. Poleg članov Misijonske družbe in jezuitske skupnosti so

To je bil slovenski prevod molitvenika, ki ga je sestavil kapucin beneške province z naslovom Hora sancta impensa ante sanctissimum Altaris Sacramentum (Čebulj 1922, 54-55).

8 Prim. Einverleibungs-Buch des frommen Vereines der Gesellschaft des süssesten Herzens Jesu, welcher in der Pfarrkirche Maria Verkündigung zur Ehre Gottes angestellt war. Laibach am 24. September 1827. 
vedno pomembnejšo vlogo pri izvajanju ljudskih misijonov imeli tudi manjši bratje (Tomšič 1981, 162). Večji pomen je veljal kategorialni pastorali. Delovali so kot kaplani v zaporih, imeli verski pouk v raznih šolah, bili so duhovni voditelji raznih cerkvenih združenj in pomagali v dušnem pastirstvu duhovnikom po župnijah; pri tem so se izkazali predvsem kot pridigarji ob različnih priložnostih v teku cerkvenega leta in kot spovedniki. Občasno so posamezne samostanske skupnosti pripravile duhovne vaje za kako posamezno kategorijo ljudi (Ambrožič 2013, 89-121).

Pomemben je postajal cerkveni tisk, zlasti od sredine stoletja dalje. Lektorji, ki so delovali v frančiškanskem modroslovnem učilišču na Kostanjevici pri Gorici med njimi je imel osrednje mesto p. Stanislav Škrabec -, so poskrbeli, da so člani tretjega reda dobili svoje povezovalno glasilo. Leta 1880 je pod uredništvom p. Stanislava Škrabca začelo izhajati njihovo glasilo Cvetje z vrtov svetega Frančiška, "časopis za naše verno ljudstvo, zlasti za ude tretjega reda sv. Frančiška«, ki je postalo pomemben izraz Škrabčevih jezikoslovnih študij in vir za slovensko cerkveno zgodovino nasploh. Manjši bratje so s podpiranjem tiska (vidni izraz tega je postala njihova lastna tiskarna, ustanovljena v nadaljevanju) utrjevali mesto Cerkve na tem področju in vzpostavljali nove oblike vezi z okoljem, v katerem so delovali.

Od tridesetih let 19. stoletja dalje so v slovenski prostor vedno pogosteje prihajale informacije o delu v misijonih, to pa je mogoče razumeti kot izraz obnovljenega zanimanje za misijonsko poslanstvo Cerkve, ki se je obnovilo po več desetletjih prekinjenih stikov med Evropo in misijonskimi deželami. Posamezniki, predvsem Friderik I. Baraga in Ignacij Knoblehar, so v cerkvena občestva na Slovenskem vnesli novo razsežnost - zanimanje za misijonsko delo in iskanje možnosti, da bi se $v$ podpiranje misijonov vključili posamezniki in skupnosti, ki drugače ne bi mogli postati aktivni udeleženci misijonskega dela. Med frančiškani, ki so se prvi odločili za misijonsko pot, so bili Ivo Levec (Turčija, Severna Amerika), Angelik Medved (Turčija), Leo Osredkar (Severna Amerika), Gvido Pelicon (Centralna Afrika), Maksimilijan Senica (Južna Amerika) in Oton Skola (Severna Amerika).

\section{Prispevek na področju župnijske pastorale}

Poleg raznih oblik pastoralnega delovanja, ki je presegalo župnijske meje, je skupnost manjših bratov veliko pozornosti namenjala prav župnijskim skupnostim in vodenju župnij (Ljubljana - Marijino oznanjenje, Nazarje, Brežice, slovenska predmestna župnija Maribor, Sveta Trojica v Slovenskih Goricah). Pastoralno delo so manjši bratje morali od vsega začetka usklajevati z župnijsko duhovščino, pri tem pa so neredko nastajale napetosti, zlasti ob vprašanju teritorialne in personalne pristojnosti. Duhovna oskrba je bila pri cerkvah, ki so jih oskrbovali manjši bratje, bolj pestra in bolj prilagodljiva glede na potrebe vernikov. Kakor je M. Ambrožič ugotovil za brežiški samostan, je bilo za ljudi pomembno, »da so se dobro počutili kot tretjeredniki ali pa kot člani katerega od nastajajočih verskih združenj« in niso toliko gledali pristojnosti domačega župnika. 
»Porciunkulski praznik z odpustki je bil vsako leto vrhunec frančiškanske zakramentalne dejavnosti in popularnosti, saj so ljudje ob tej priložnosti množično prihajali k sv. spovedi in obhajilu, hkrati pa je bilo omenjeno praznovanje tudi velik družbeni dogodek. Frančiškansko cerkev so sicer polnili predvsem dobri pridigarji in nekatere pobožnosti, zlasti pobožnost križevega pota.« (Ambrožič 2013, 117)

Takšno trditev je mogoče izreči za vsakega od samostanov manjših bratov na slovenskih tleh v 19. stoletju.

\section{Sklep}

Čeprav so imeli manjši bratje frančiškani v cerkvenih občestvih na Slovenskem ob začetku 19. stoletja ustaljeno mesto in večje število ustanov iz prejšnjega obdobja kakor druge redovne skupnosti, so se kljub temu morali prilagajati in iskati svoje lastne odgovore na nove izzive, ki so jih prinašali čas in spremembe v delovanju Cerkve. Veliko pozornosti in moči so namenjali odpravljanju posledic ukrepov političnih oblasti, ki so v odnosih do Cerkve in do izrazov praktičnega verskega življenja uveljavljale racionalistične in janzenistične ideje in so izhajale iz prejšnjega obdobja. Več moči so posvečali obnavljanju tradicionalnih oblik verskega življenja in cerkvenim združenjem in prevzemali pomembnejše mesto tako $v$ župnijski pastorali kakor pri skrbi za delovanje romarskih krajev. Skrbeli so za vzgojno-izobraževalno delo v osnovnih šolah in na gimnazijah ter imeli učilišče za pripravo učiteljev na teh šolah, to pa jim je zagotavljalo možnost, da so bistveno posegali v dogajanje v posameznih okoljih, kjer so bili njihovi samostani. Za izobraževanje duhovniških kandidatov so imeli svoje lastno bogoslovno semenišče. Čeprav je osrednje vodstvo Cerkve kazalo željo po večji centralizaciji, so redovne skupnosti ponovno ovrednotile pomen krajevnih skupnosti in svojega lastnega predstojnika, ki je prevzemal vedno večjo odgovornost za delovanje zaupanih mu bratov. $V$ tem smislu so se v okviru krajevnih skupnosti kazale večje silnice po decentralizaciji. Ovrednoten je bil pomen eksemptnosti v odnosu do vsakokratnega predstojnika krajevne Cerkve. Manjši bratje so v teku 19. stoletja na Slovenskem ponovno pokazali veliko mero sposobnosti za prilagajanje in moči za prenovo svojih lastnih vrst. S tem so potrdili mesto, ki so ga imeli v Cerkvi med Slovenci že predtem, in hkrati dodali nove značilnosti, ki so jim to mesto še bolj utrdile. 


\section{Reference}

Ambrožič, Matjaž. 2013. Življenje in dejavnosti brežiških frančiškanov v 19. stoletju. S patri smo si bili dobri: Tri stoletja brežiških frančiškanov, 89-121. Zbornik znanstvenih razprav. Krško: Društvo za oživitev mesta Brežice.

Bahčič, Robert. 2007. Čudež, ki traja 800 let: Zgodovina Frančiškove karizme v svetu in pri nas. Ljubljana: Brat Frančišek.

Cevc, Emilijan, ur. 1993. 500 let frančiškani v Kamniku. Zbornik referatov zgodovinskega simpozija 1992. Kamnik: Kulturni center.

Čebulj, Regalat. 1922. Janzenizem na Slovenskem in frančiškani. Ljubljana: Frančiškanska provincija Slovenije.

Damiš, Henrik. 1914. Marija Pomagaj na Brezju. Brezje: Cerkveno predstojništvo.

Dolinar, France M. 1991. Jožefinizem in janzenizem. V: Zgodovina Cerkve na Slovenskem, 153-171. Celje: Mohorjeva družba.

Frank, Karl Suso. 2010. Geschichte des christlichen Mönchtums. Darmstadt: WBG.

Furlan, Alfonz. 1926. Češčenje sv. Frančiška Asiškega v Sloveniji. Cvetje z vrtov sv. Frančiška 43 [Slavnostni izvod $v$ spomin sedme stoletnice smrti sv. Frančiška], 26-27.

Heric, Kalist. 1894. Frančiškanska cerkev Matere Milosti v Mariboru. Cvetje z vrtov sv. Frančiška 13, 33-35.

Jedin, Hubert, ur. 1993. Handbuch der Kirchengeschichte (ital. prevod). Zv. 8/1. Milano: Jaca Book.

Kogoj, Jasna. 1982. Uršulinke na Slovenskem. Izola: Uršulinski provincialat.

Krajnc, Silvin, ur. 2000. Frančiškani v Ljubljani: Samostan, cerkev in župnija Marijinega oznanjenja. Ljubljana: Samostan in župnija Marijinega oznanjenja.

Landergott, Emerik. 1904. Sv. Trojica v Slovenskih goricah. Cvetje z vrtov sv. Frančiška 21, 29ss.

Martina, Giacomo. 1995. Storia della Chiesa da Lutero ai nostri giorni. Zv. 3. Brescia: Morcelliana.

Ožinger, Anton. 2000. Frančiškanski samostan v Ljubljani od preselitve 1784 do leta 1903. V: Frančiškani v Ljubljani: Samostan, cerkev in župnija Marijinega oznanjenja, 201-218. Ljubljana: Samostan in župnija Marijinega oznanjenja.

Papež, Viktor. 1983. Anton Martin Slomšek - učitelj duhovnosti redovnikom. V: Slomškov simpozij v Rimu, 77-98. Rim: Mohorjeva družba.

Pokorn, France. 1908. Šematizem duhovnikov in duhovnij v ljubljanski nadškofiji I. 1788. Ljubljana: Škofijski ordinariat.
Schmiedl, Joachim. 2004. An Assessment of the Histories of Religious Communities in Germany. Religious Institutes in Western Europe in the $19^{\text {th }}$ and $20^{\text {th }}$ Century: Historiography, Research and Legal Position, 71-81. Leuven: Leuven University Press.

Slovenski biografski leksikon. 1925-1991. 4 zv. Ljubljana: Zadružna gospodarska banka; Slovenska akademija znanosti in umetnosti.

Škofljanec, Jože. 2000. Red manjših bratov (O.F.M) in provinca sv. Križa. V: Frančiškani v Ljubljani. Samostan, cerkev in župnija Marijinega oznanjenja, 9-79. Ljubljana Samostan in župnija Marijinega oznanjenja.

- - -, ur. 2013. S patri smo si bili dobri: Tri stoletja brežiških frančiškanov. Krško-Ljubljana: Društvo za oživitev mesta Brežice.

Špelič, Miran. 2010. Visoko šolstvo v redu manjših bratov od ustanovitve vikarije - Province sv. Križa do ustanovitve Univerze v Ljubljani. V: Teološki študij na Slovenskem, 199-270. AES 32. Ljubljana: Inštitut za zgodovino Cerkve.

Šuštar, Branko. 1993. Prispevek frančiškanov $h$ kamniškemu ljudskemu šolstvu. V: 500 let frančiškanov v Kamniku. Zbornik referatov zgodovinskega simpozija 1992, 77-101. Kamnik: Kulturni center.

- - - 2013. Prispevek frančiškanov k osnovnemu šolstvu v Brežicah. V: S patri smo si bili dobri. Tri stoletja brežiških frančiškanov, 321-352. Zbornik znanstvenih razprav. Krško: Društvo za oživitev mesta Brežice.

Tominec, Angelik. 1926-1930. Pregled zgodovine frančiškanov med Slovenci. Cvetje z vrtov sv. Frančiška 43-47.

Tomšič, Bernardin. 1981. Ljudski misijoni v naši provinci. Poročila slovenske frančiškanske province sv. Križa, 35,162ss.

Wolf, Adam. 1871. Die Aufhebung der Klöster in Innerösterreich: 1782-1790; ein Beitrag zur Geschichte Kaiser Josef's II. Dunaj: Wilhelm Braumüller.

Zgodnja danica. 1855-1856. Katoliški cerkveni list. Ljubljana: Janez Krizostom Pogačar.

Zschokke, Hermann. 1894. Die theologische Studien und Anstalten der katholischen Kirche in Oesterreich. Dunaj: Wilhelm Braumüller. 